$\underline{\text { https://doi.org/10.18778/1427-9711.13.01 }}$

\title{
ARTYKULY
}

Jan Degirmendžić, Marek Walisch, Aleksander Szmidt

Katedra Geografii Fizycznej, Zakład Dynamiki Środowiska i Bioklimatologii

Wydział Nauk Geograficznych, Uniwersytet Łódzki

Artykuł wpłynął do redakcji 19.04.2014; po recenzjach zaakceptowany 23.09.2014

\section{POLA OPADÓW W POLSCE ZWIĄZANE Z NIŻAMI Vb VAN BEBBERA ${ }^{1}$}

\section{PRECIPITATION FIELDS IN POLAND ASSOCIATED WITH VAN BEBBER'S Vb CYCLONES}

W artykule przedstawiono przebieg średniej trajektorii niżów Vb van Bebbera w skali roku. Wyznaczono najbardziej opadotwórczy odcinek trajektorii, tzn. region występowania cyklonów, które wywołują najwyższe opady w Polsce. Skonstruowano mapę średnich sum dobowych opadu związanych $\mathrm{z}$ niżami $\mathrm{Vb}$ oraz mapę opadów maksymalnych informującą o tym, jaka była najwyższa wartość opadu w danej stacji meteorologicznej w okresie 1958-2008 związana z wystąpieniem niżu Vb na wyróżnionym - najbardziej opadotwórczym - odcinku trajektorii.

Szlak Vb rozpoczyna się na Morzu Balearskim, a kończy nad południową Finlandią. Najwyższe opady w Polsce związane są z niżami usytuowanymi w sąsiedztwie środkowego odcinka trajektorii - nad wschodnimi Węgrami, zachodnią Rumunią lub południową Słowacją. Najwyższe średnie sumy opadów można zaobserwować w Polsce Południowo-Wschodniej. Maksima występują w Kotlinie Żywieckiej, w Tatrach i na Wyżynie Lubelskiej. Maksymalny opad dobowy związany z niżem Vb wystąpił na Śnieżce i osiągnął wartość 129,2 mm.

Słowa kluczowe: Polska, niże śródziemnomorskie Vb, trajektoria, opady

\footnotetext{
${ }^{1}$ Opracowanie wykonane w ramach grantu NCN N N306313739.
} 


\section{Wprowadzenie}

Szlak Vb wyróżnia się południkowym ułożeniem na tle innych szlaków niżowych nad Europą - przebiega znad Adriatyku przez środkowo-wschodnią Europę aż do granic Finlandii. Liczba wędrujących tym szlakiem cyklonów nie jest mała; J. Hann (1906) podawał, że w latach 1876-1889 stanowiły one około $15 \%$ wszystkich cyklonów występujących nad Europą.

Osobliwa trajektoria jest przyczyną istotnej roli, jaką odgrywają śródziemnomorskie cyklony $\mathrm{Vb}$ w kształtowaniu warunków klimatycznych, a zwłaszcza wielkości opadów atmosferycznych w Europie środkowo-wschodniej. Cyklony te niosą na północ ogromne zasoby wilgoci, a na ich zachodnich peryferiach rozwija się cyrkulacja napotykająca orograficzne bariery Karpat Zachodnich, Sudetów i Alp, co sprzyja powstawaniu wysokich opadów w tym regionie. Niże śródziemnomorskie powodują powodzie albo śnieżyce w Polsce i krajach sąsiednich; przykładami z ostatnich lat są m.in. powodzie w Czechach i Polsce w 2010 r. oraz obfite opady śniegu w krajach Europy Środkowej i na Ukrainie w okresie od jesieni 2012 r. do wiosny 2013 r. Nieco wcześniej - w 1997 r. miała miejsce ,powódź tysiąclecia” w Polsce i Czechach.

Układy cyklonalne wędrujące szlakiem $\mathrm{Vb}$ stanowią ważny czynnik ryzyka wystąpienia ekstremalnych zjawisk hydrometeorologicznych - zwłaszcza długotrwałych i intensywnych opadów w całym regionie środkowej i środkowo-wschodniej Europy (m.in. Ulbrich i in. 2003; Mudelsee i in. 2004; Ustrnul, Czekierda 2009). Spektakularność tego zjawiska powoduje, że większość prac dotyczących niżów Vb i skutków hydrologicznych ich wystąpienia stanowią studia przypadku (m.in. Ulbrich i in. 2003; Rezáčová i in. 2005; Sodemann i in. 2009; Bissolli i in. 2011).

Prezentowana $\mathrm{w}$ niniejszej pracy analiza ma charakter klimatologiczny uwzględnia wszystkie niże śródziemnomorskie odnotowane w bazie M. Serreze'a (2009) oraz związane z nimi pola opadów w latach 1958-2008. Cele opracowania są następujące:

1. Określenie przebiegu trajektorii $\mathrm{Vb}$ w skali roku.

2. Wyróżnienie najbardziej opadotwórczego odcinka trajektorii.

3. Skonstruowanie średniego pola opadów w Polsce związanego z niżami Vb.

4. Określenie rozkładu maksymalnych dobowych opadów w Polsce wywołanych przez niże $\mathrm{Vb}$.

\section{Dane}

W pracy wykorzystano bazę o niżach na półkuli północnej, skonstruowaną przez M. Serreze'a (2009). Baza ta jest wynikiem zastosowania automatycznej procedury detekcji i śledzenia przemieszczających się układów niskiego ciśnienia. Oznaczono przypadki cyklogenezy oraz cyklolizy. Lista niżów obejmuje 
układy rozwijające się na półkuli północnej od 1 stycznia 1958 r. do 31 grudnia 2008 r. Aby wyselekcjonować niże Vb, posłużono się siatką czterech południków i czterech równoleżników, która określa położenie m.in. sektora wschodniego - znajdującego się na wschód od Polski, oraz sektora południowego (rys. 1). Niż $\mathrm{Vb}$ spełnia poniższe kryteria:

- na dowolnym etapie rozwoju niżu jego centrum znajduje się w obrębie basenu Morza Śródziemnego,

- na późniejszym etapie rozwoju centrum niżu przemieszcza się przez sektor południowy, a następnie sytuuje się w sektorze wschodnim.

Wyselekcjonowano 80 takich układów. Podobną metodę identyfikacji układów Vb zastosowali K. Nissen i in. (2012).

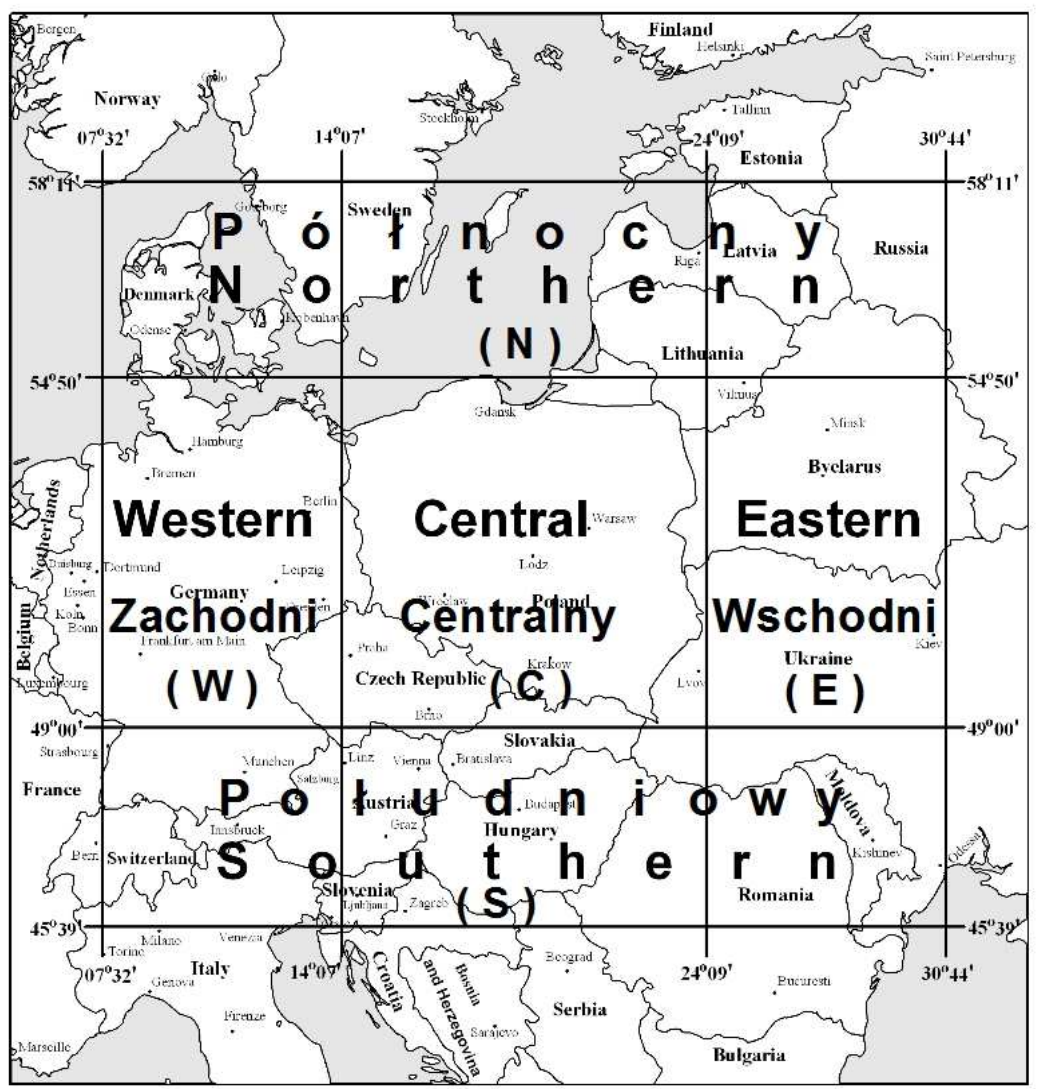

Rys. 1. Siatka równoleżników i południków wyznaczająca sektory Europy Środkowo-Wschodniej: W, E, S, N i C. W niniejszym opracowaniu, do wyróżnienia szlaków Vb, wykorzystano sektor E (wschodni) oraz S (południowy)

Fig. 1. System of parallels and meridians defining sectors of Central and Eastern Europe

$-\mathrm{W}, \mathrm{E}, \mathrm{S}, \mathrm{N}$ and $\mathrm{C}$. In current analysis, in order to select $\mathrm{Vb}$ tracks, $\mathrm{E}$ (eastern) and $\mathrm{S}$ (southern) sectors were utilized 
Analizę opadów oparto na seriach sum dobowych z 66 stacji meteorologicznych w Polsce z wielolecia 1958-2008. Dane uzyskano z Instytutu Meteorologii i Gospodarki Wodnej. Lokalizację stacji przedstawiono na rys. 2.

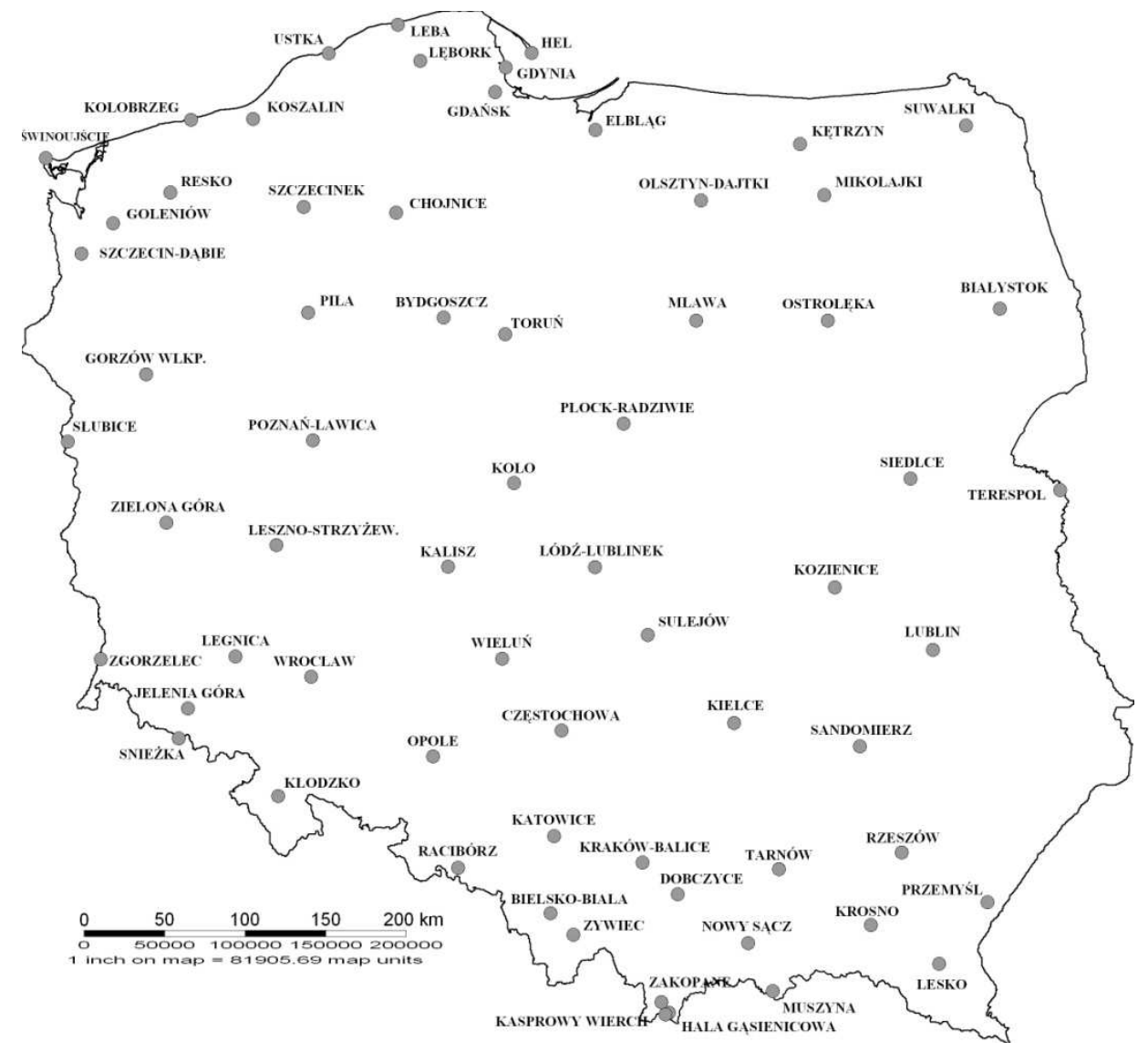

Rys. 2. Położenie stacji meteorologicznych w Polsce

Fig. 2. Location of meteorological stations in Poland

\section{Metody}

Baza danych o niżach M. Serreze'a zawiera m.in. współrzędne geograficzne centrów niżów oraz informacje o tym, czy dany etap rozwoju niżu jest cyklogenezą czy cyklolizą. Dane te posłużyły do wizualizacji trajektorii niżów, spośród których wybrano układy $\mathrm{Vb}$ według ww. kryteriów. Sporządzono rozkład częstości tych niżów w siatce $10^{\circ} \times 5^{\circ}$, następnie przeliczono wartości na jeden termin obserwacji i powierzchnię gridu $10^{9} \mathrm{~km}^{2}$. Na mapie częstości określono przebieg trajektorii, jako linii przeprowadzonej przez maksima 
rozkładu przestrzennego. Koniec i początek trajektorii określa wartość 1 izolinii częstości. Kolejne punkty trajektorii wyznaczono z rozdzielczością co $1^{\circ} \mathrm{dłu}-$ gości i szerokości geograficznej.

Aby wyróżnić najbardziej opadotwórczy odcinek trajektorii, określono terminy wystąpienia niżów Vb w okręgach o promieniu $250 \mathrm{~km}$ i środkach w kolejnych punktach trajektorii (od 1 do 34). Uśredniono sumy dobowe opadów z 66 stacji meteorologicznych w Polsce z ww. terminów. W ten sposób określono zmiany średniego opadu w Polsce zachodzące wraz z wędrówką niżu Vb wzdłuż trajektorii. Dodatkowo analogicznie przedstawiono zmiany maksymalnej dobowej sumy opadu, wybranej spośród 66 stacji.

Maksymalna wartość średniego oraz maksymalnego opadu (wybranego spośród 66 stacji w Polsce) jest związana z określonym odcinkiem trajektorii, tzn. jest generowana przez niże znajdujące się w obrębie odpowiedniego okręgu o środku w danym punkcie trajektorii. Pole opadów w Polsce przedstawia wartości średnie $\mathrm{z}$ okresów wystąpienia niżów $\mathrm{Vb}$ w najbardziej opadotwórczym segmencie trajektorii. Skonstruowano także mapę najwyższych sum dobowych opadu w Polsce związanych z niżami Vb, tzn. wartości maksymalnych wybranych dla każdej stacji osobno spośród okresów wystąpienia niżów na odcinku najbardziej opadotwórczym. Mapa ta odpowiada na pytanie, jaki był najwyższy opad związany z niżem Vb na danej stacji w latach 19582008.

\section{Trajektoria niżów Vb}

Średnia trajektoria $\mathrm{Vb}$ rozpoczyna się na Morzu Balearskim, następnie przebiega na północny-wschód nad Korsykę, przekracza Półwysep Apeniński oraz północny Adriatyk. Na dalszym etapie wędrówki niże śródziemnomorskie kierują się nad Słowenię i Węgry. Odcinek nad Węgrami ma charakter równoleżnikowy - wiąże się to prawdopodobnie z orografią Karpat. Nad północno-zachodnią Rumunią niże Vb zmieniają kierunek na północno-wschodni i przedostają się nad zachodnią Ukrainę przez przewężenie Karpat między Bieszczadami a Gorganami. Następnie układy niżowe przemieszczają się na północ przez Białoruś oraz kraje nadbałtyckie. Trajektoria Vb kończy się nad południową Finlandią (rys. 3).

\section{Najbardziej opadotwórczy odcinek trajektorii Vb}

Średnia dobowa suma opadu dla Polski osiąga maksimum, kiedy niże Vb znajdują się w pobliżu 18. punktu trajektorii, tzn. usytuowane są nie dalej niż $250 \mathrm{~km}$ od punktu o współrzędnych $\lambda=21^{\circ} \mathrm{E}, \varphi=47^{\circ} \mathrm{N}$ (rys. 4). Wartość 


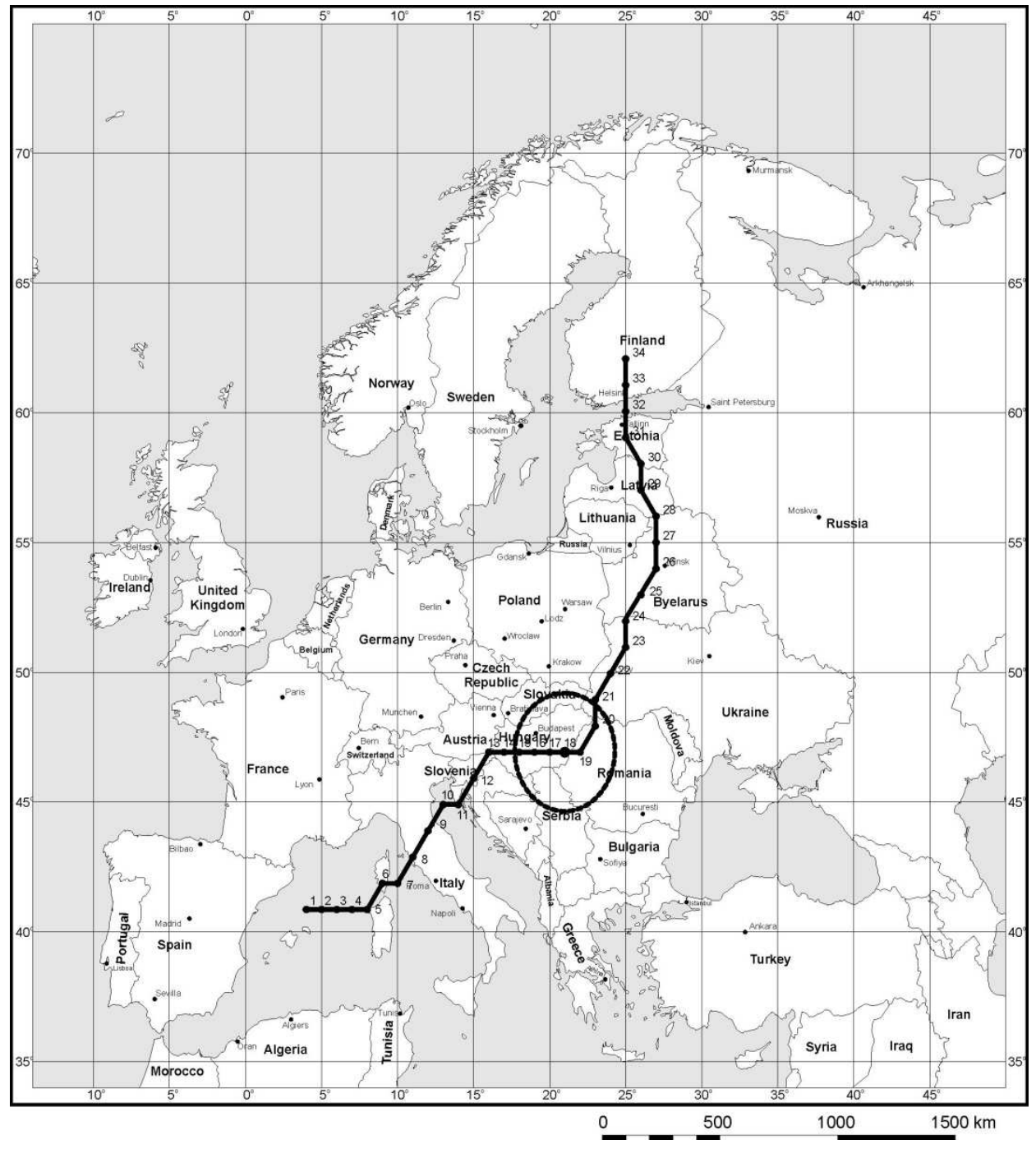

Rys. 3. Średnia roczna trajektoria cyklonów Vb w latach 1958-2008. Zaznaczono okrąg o promieniu $250 \mathrm{~km}$ i środku w punkcie 18 . Niże występujące w granicach tego okręgu wywołują najwyższy opad w Polsce

Źródło mapy konturowej: GoldenSoftware MapViever 7 Samples Files

Fig. 3. Average annual trajectory of Vb cyclones in the period 1958-2008. Circle with aradius of $250 \mathrm{~km}$ and center at point 18 is depicted. Lows occurring within this circle produce the highest rainfall in Poland Contour map source: GoldenSoftware MapViever 7 Sample Files 


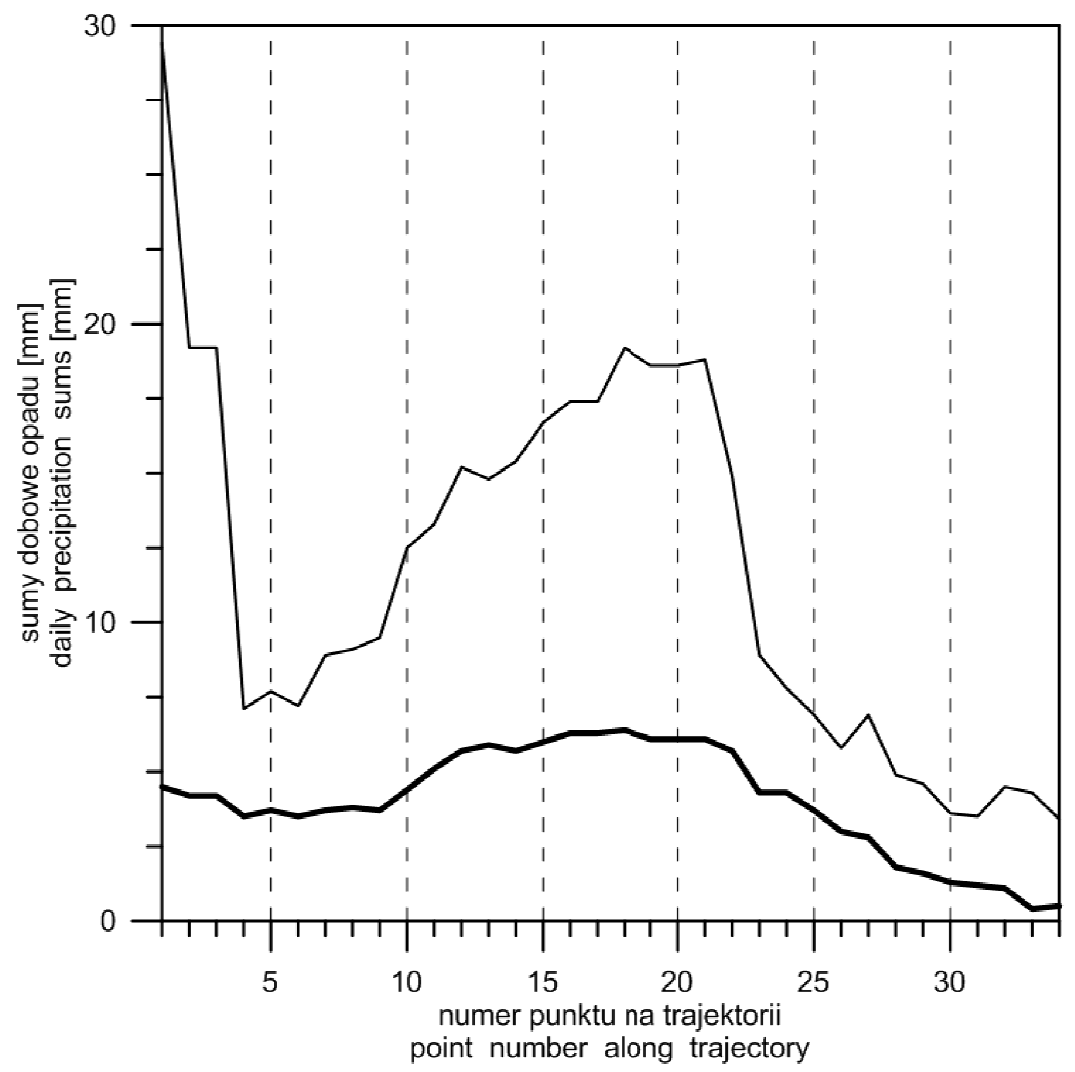

Rys. 4. Dobowe sumy opadów w Polsce w zależności od pozycji niżów śródziemnomorskich na średniej trajektorii Vb w okresie 1958-2008. Linia pogrubiona - średnia z 66 stacji meteorologicznych w Polsce.

Linia cienka - wartość maksymalna opadu spośród 66 stacji.

Wartości opadu uśredniono z okresów, kiedy niże $\mathrm{Vb}$ znalazły się w granicach okręgu o promieniu $250 \mathrm{~km}$ i środku w danym punkcie trajektorii

Fig. 4. Daily precipitation totals in Poland depending on the position of the Mediterranean lows on average trajectory $\mathrm{Vb}$ in the period 1958-2008.

Bolded line - the average of 66 meteorological stations in Poland.

Thin line - maximum precipitation of 66 stations.

Precipitation values were averaged from the dates when $\mathrm{Vb}$ cyclones were situated within a circle of radius $250 \mathrm{~km}$ centered at a given trajectory point

średnia opadu osiąga $6,4 \mathrm{~mm}$. Z tym samym punktem trajektorii związany jest maksymalny opad - 19,2 mm - charakterystyczny dla stacji Bielsko-Biała, uśredniony z okresów, kiedy niże Vb wystąpiły w pobliżu ww. punktu 18 . (rys. 4). Zmiany opadów w Polsce, związane z przemieszczaniem się niżów wzdłuż trajektorii Vb, cechuje asymetria. Początkowy odcinek trajektorii generuje wyższe opady w porównaniu z końcowym odcinkiem. Niże znajdujące się 
w basenie Morza Śródziemnego wywołują średni opad w Polsce ok. 3-4 mm. Maksymalne opady zmierzone na danej stacji mogą osiągać $30 \mathrm{~mm}$ - jest to wartość średnia w stacji Hala Gąsienicowa, obliczona z okresów, kiedy niże $\mathrm{Vb}$ znajdowały się w okolicy punktu pierwszego trajektorii (rys. 4). Wysokie opady w rejonach górskich południowej Polski występujące w okresie, kiedy niże śródziemnomorskie usytuowane są na początku trajektorii $\mathrm{Vb}$, mogą być związane z zaburzeniem zachodniego przepływu i rozwijającą się linią zbieżności prądów powietrza w obrębie bruzdy niskiego ciśnienia, która łączy niż śródziemnomorski z niżem usytuowanym zazwyczaj nad Bałtykiem. Taka sytuacja synoptyczna powoduje składowe północne w przepływie powietrza na obszarze Sudetów i/lub Tatr.

Obie serie opadowe prezentowane na rys. 4 osiągają maksima, gdy niże $\mathrm{Vb}$ znajdują się na południe od granic Polski (w sąsiedztwie 18. punktu trajektorii). Wraz z dalszą wędrówką układów niżowych na północ opady w Polsce maleją. Wartości bliskie zeru (średnie dla Polski) osiągają dla 34. punktu trajektorii. Średnia suma dobowa opadu w żadnej stacji w Polsce nie przekracza 3,4 mm w okresie, gdy niże usytuowane są na końcowym etapie szlaku Vb.

\section{Pola opadów w Polsce}

Pole opadów w Polsce, związane z najbardziej opadotwórczym segmentem trajektorii (sąsiedztwo 18. punktu), cechuje się wyraźnie zorientowanym w przestrzeni gradientem poziomym. Opady maleją w kierunku północno-zachodnim. Pas podwyższonych wartości rozciąga się przez południowo-wschodnią Polskę. Średnie wartości sumy dobowej opadu w tym rejonie Polski nie spadają poniżej $7 \mathrm{~mm}$. Obszarem o najwyższych średnich sumach dobowych opadu jest Kotlina Żywiecka z przylegającymi do niej pasmami Beskidu Śląskiego, Żywieckiego i Małego (rys. 5). Maksima osiągają tam $19 \mathrm{~mm}$. Beskid Śląski wraz z Żywieckim zbiegają się w kierunku zachodnim, a obniżenie pomiędzy nimi jest niewielkie. W wyniku tego pasma te tworzą swoistą pułapkę orograficzną - masy powietrza napływające z kierunku północno-wschodniego i opuszczające Kotlinę Żywiecką zmuszone są uczestniczyć w ruchach wznoszących. Dlatego w pierwszej kolejności zlewnia Soły, a następnie zlewnia Dunajca są najbardziej wrażliwe na opady związane z niżami Vb.

Kolejnym obszarem Polski o zdecydowanie wyższych opadach niż pozostała część kraju jest pasmo Tatr. Średnie sumy dobowe opadu w tym rejonie sięgają prawie $18 \mathrm{~mm}$ (Kasprowy Wierch - 17,5 mm, Hala Gąsienicowa - 17,6 mm). Strefa podwyższonych opadów rozciąga się od Tatr i Kotliny Żywieckiej na północ i wschód i obejmuje południową część Wyżyny Krakowsko-Częstochowskiej oraz pozostałą część pasma Beskidów Zachodnich wraz z przylegającym do niego Pogórzem Karpackim. Średnie opady na tych obszarach zawierają się w zakresie od 9 do $11 \mathrm{~mm}$. 


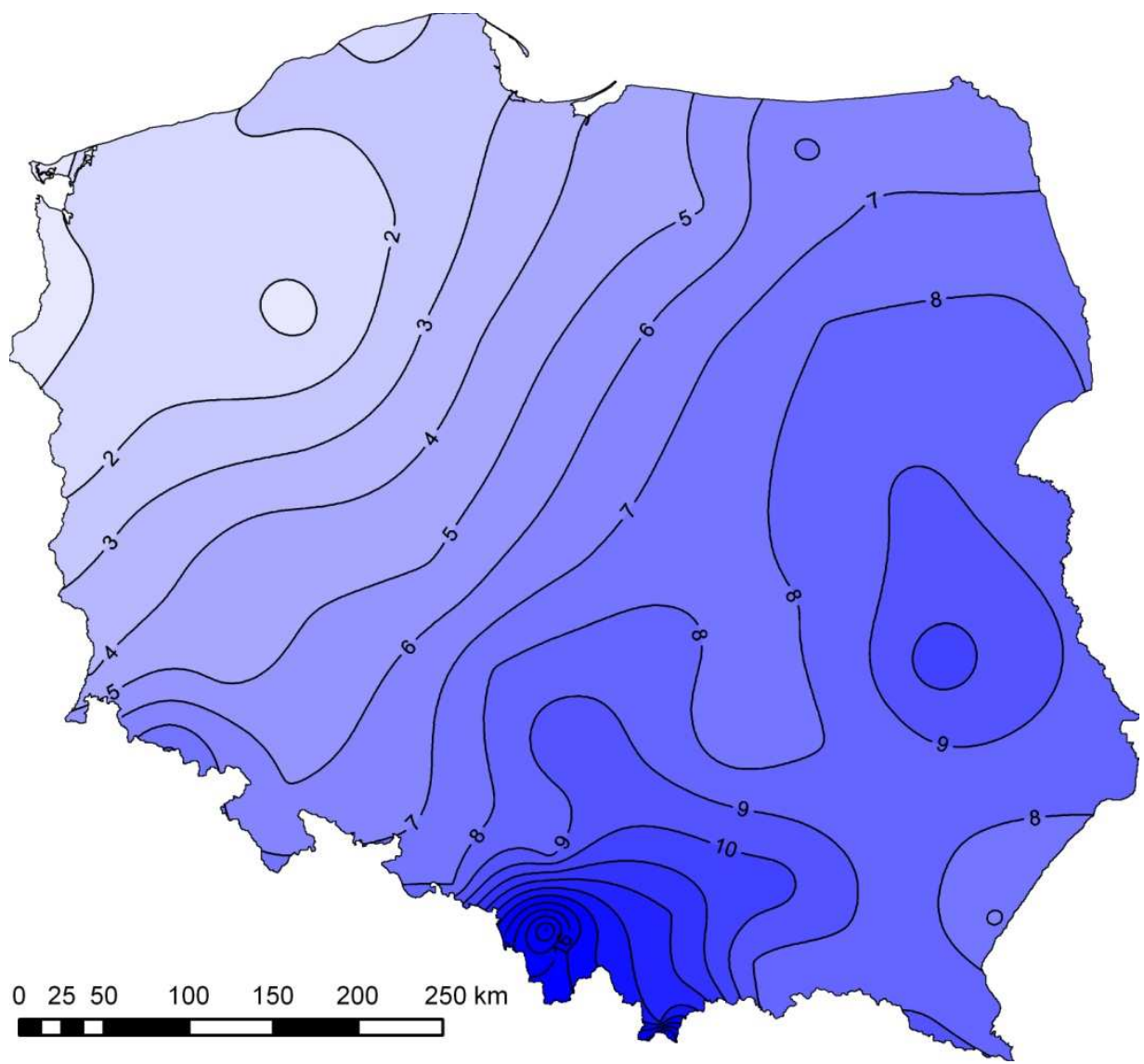

Rys. 5. Rozkład średnich dobowych sum opadu w Polsce [mm] związanych z niżami śródziemnomorskimi, usytuowanymi na najbardziej opadotwórczym odcinku trajektorii Vb w okresie 1958-2008.

Wartości uśredniono z okresów, kiedy układy niżowe wystąpiły w granicach okręgu o środku w punkcie 18. trajektorii

Fig. 5. Distribution of mean daily precipitation totals in Poland [mm] related to Mediterranean cyclones situated at the most rainfall-efficient section of the $\mathrm{Vb}$ track in the period 1958-2008.

Values were averaged from the dates when $\mathrm{Vb}$ cyclones were situated within a circle centered at point $18^{\text {th }}$ of the trajectory

Niewielki efekt orograficzny związany z podwyższeniem sum opadów atmosferycznych występuje również na Wyżynie Lubelskiej (>9 mm). Podwyższone wartości opadu można zauważyć także w Sudetach - do $7 \mathrm{~mm}$ w Kotlinie Kłodzkiej i do $8 \mathrm{~mm}$ w Karkonoszach (Śnieżka - 8,3 mm) (rys. 5). Podkreślić należy, że prezentowane sumy opadu są wartościami uśrednionymi z wszystkich okresów, kiedy niże $\mathrm{Vb}$ usytuowane były nie dalej niż w odległości $250 \mathrm{~km}$ od 
18. punktu trajektorii. W kierunku na północny-zachód opady maleją - nad zachodnią częścią Pojezierza Pomorskiego średnie sumy dobowe nie przekraczają $2 \mathrm{~mm}$, a przy granicy z Niemcami wartości są mniejsze niż $1 \mathrm{~mm}$ (rys. 5).

Maksymalne sumy dobowe związane z niżami $\mathrm{Vb}$ przedstawiono na rys. 6 . W rozkładzie opadów zaznaczają się obszary opisane powyżej, czyli charakteryzujące się podwyższoną średnią sumą opadu. Są to: Kotlina Żywiecka, Tatry, Sudety oraz Wyżyna Lubelska. Na pierwszym miejscu jednak plasują się Karkonosze, a nie Kotlina Żywiecka, która cechowała się najwyższą średnią sumą opadu. Najwyższą sumę dobową zanotowano na Śnieżce - 129,2 mm. 82,4 mm deszczu spadło w Jeleniej Górze. Nieco mniej - 76,2 mm - w Zgorzelcu. Opady w Karkonoszach związane z układami Vb pojawiają się prawdopodobnie rzadziej niż w Karpatach i występują przy bardziej zachodnim przebiegu trajektorii. Skądinąd jednak wiemy, że sytuacje synoptyczne powodujące zagrożenie powodziowe w dorzeczu Bobru i Kwisy powtarzały się dość często w obu dorzeczach na początku XX w. Skłoniło to Niemców do wybudowania w Sudetach pierwszych zbiorników retencyjnych o charakterze przeciwpowodziowym (na Bobrze Zbiornik Pilchowicki oddany do użytku w 1912 r., na Kwisie Zbiornik Leśniański z 1905 r. oraz Zbiornik Złotnicki oddany do użytku w 1924 r.).

W Kotlinie Żywieckiej maksymalne opady związane z niżami śródziemnomorskimi przekroczyły nieznacznie $80 \mathrm{~mm}$ (Żywiec - 84,8 mm; Bielsko-Biała $81,3 \mathrm{~mm})$. Podobne sumy opadów zaobserwowano w Tatrach: na Hali Gąsienicowej $-85,7 \mathrm{~mm}$, a na Kasprowym Wierchu $-78,1 \mathrm{~mm}$. W Zakopanem opad maksymalny był niższy $-65,8 \mathrm{~mm}$. Na obszarze wschodniej Polski zaznaczają się dwa rejony podwyższonych opadów: pierwszy, związany z Wysoczyzną Białostocką, cechuje się opadem nieco ponad $80 \mathrm{~mm}$; drugi, obejmujący Wyżynę Lubelską, o wartościach przekraczających $70 \mathrm{~mm}$. Pozostałe strefy podwyższonych opadów nie są związane z orografią - na Równinie Opolskiej i Wyżynie Przedborskiej opady przewyższają nieznacznie $60 \mathrm{~mm}$, na Pojezierzu Leszczyńskim sumy dobowe opadu osiągają wartości nieco powyżej $70 \mathrm{~mm}$. Pozostałe dwa obszary podwyższonych opadów sytuują się w Kotlinie Toruńskiej oraz na Pobrzeżu Koszalińskim i Pojezierzu Bytowskim.

\section{Wnioski}

Szlak $\mathrm{Vb}$ rozpoczyna się na zachód od Korsyki, a kończy nad południową Finlandią. Średnią trajektorię Vb można podzielić na dwa odcinki: pierwszy o przebiegu z południowego-zachodu na północny-wschód, drugi o przebiegu południkowym. W rejonie wyraźnej zmiany orientacji biegu trajektorii - w sąsiedztwie punktu 18. - znajduje się najbardziej opadotwórczy odcinek trajektorii. Niże, które znajdują się w sąsiedztwie tego punktu, czyli nad 


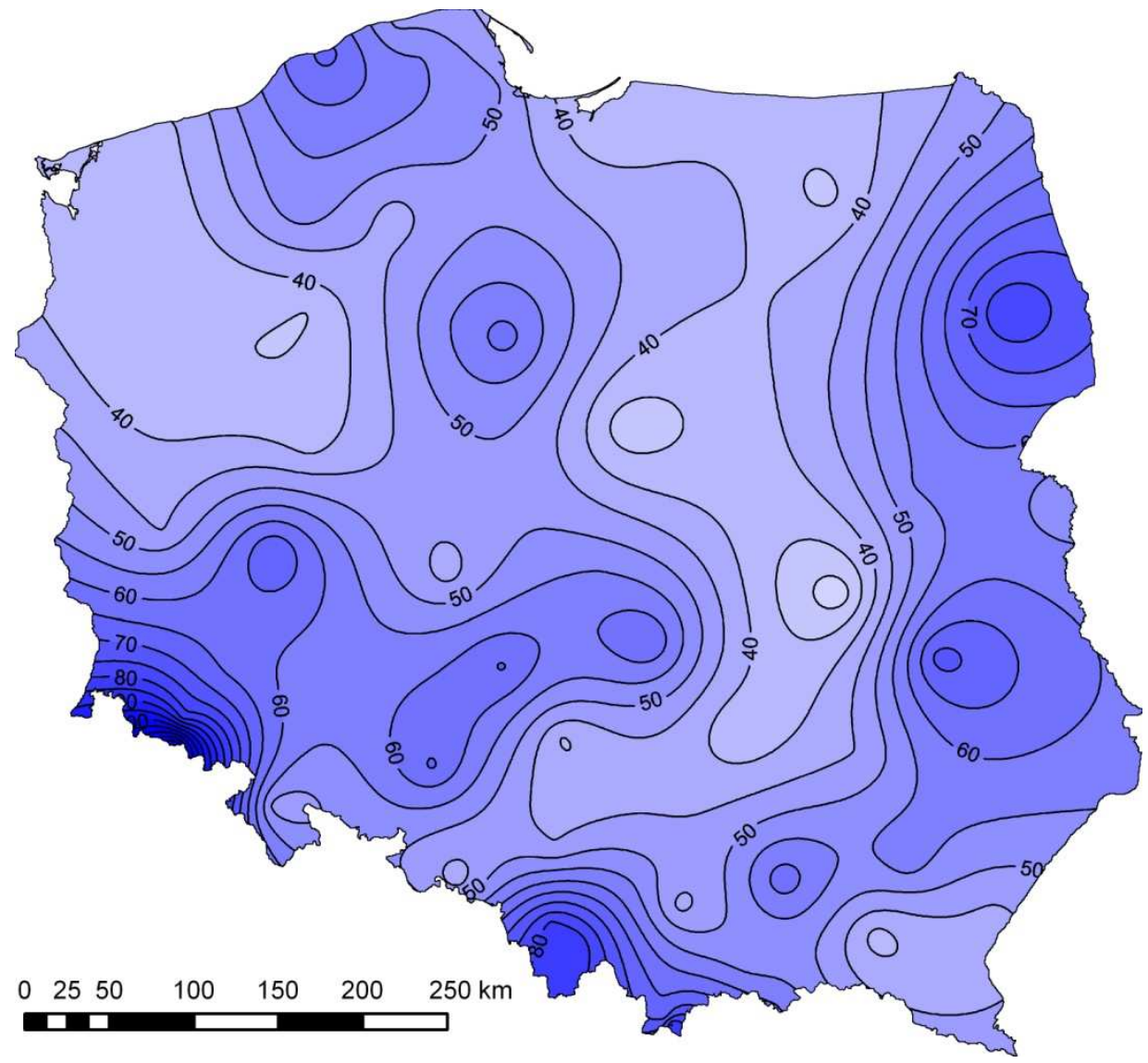

Rys. 6. Rozkład maksymalnych dobowych sum opadu w Polsce [mm], związanych

z niżami śródziemnomorskimi usytuowanymi na najbardziej opadotwórczym odcinku trajektorii Vb w okresie 1958-2008. Wartości wyselekcjonowano z okresów, kiedy układy niżowe wystąpiły w granicach okręgu o środku w punkcie 18. trajektorii

Fig. 6. Distribution of maximum daily precipitation totals in Poland [mm] related to Mediterranean cyclones situated at the most rainfall-efficient section of track $\mathrm{Vb}$ in the period 1958-2008. Values were selected from the dates when Vb cyclones were situated within a circle centered at point $18^{\text {th }}$ of the trajectory

wschodnimi Węgrami, zachodnią Rumunią lub południową Słowacją wywołują najwyższe opady w Polsce. Warto zauważyć, że z niżami Vb, znajdującymi się na wschód od Polski, czyli w sąsiedztwie dalszych punktów trajektorii, związane są już nieco mniejsze opady. Dobowe sumy opadu uśrednione z wszystkich okresów, kiedy niże znajdowały się w sąsiedztwie punktu 18. trajektorii Vb są wyraźnie wyższe w Polsce południowo-wschodniej - maksima usytuowane są na obszarze Beskidu Śląskiego, Żywieckiego oraz Tatr i Wyżyny Lubelskiej. Rozkład ten wykazuje wyraźne związki z orografią. Maksymalne opady 
związane z niżami $\mathrm{Vb}$ cechują się prawdopodobnie mieszaną genezą - opady na południu kraju (Karkonosze, Kotlina Żywiecka, Tatry, przedpole Wyżyny Małopolskiej i Śląskiej) oraz na wschodzie (Wysoczyzna Białostocka, Wyżyna Lubelska) związane są z wymuszonym przez ukształtowanie terenu ruchem wstępującym, natomiast opady w północnej części kraju nie wykazują związku $\mathrm{z}$ orografią i prawdopodobnie mają charakter frontalny lub konwekcyjny.

Zastanawiający jest fakt relatywnie niskich maksymalnych i średnich opadów dobowych w Kotlinie Kłodzkiej, która słynie z letnich powodzi. Fakt ten jest jednak zgodny z rozkładem opadów z lipca 1997 r., prezentowanym przez Z. Kundzewicza i in. (2005): maksima opadu występują poza obrębem Kotliny Kłodzkiej - w Karkonoszach i w pasie rozciągającym się między Kotliną Kłodzką a Kotliną Żywiecką. Warto również zaznaczyć, że cyklony zazwyczaj traktowane w literaturze jako $\mathrm{Vb}$, np. Xolska, Zoe, Isle, Axel (Ulbrich i in. 2003), w niniejszym opracowaniu nie zostały zaliczone do tej klasy z uwagi na przesunięcie ich trajektorii na zachód. Układy te przeszły przez terytorium Polski, dlatego zaliczono je do klasy centralnej niżów śródziemnomorskich (Degirmendžić, Kożuchowski, w druku).

\section{Podziękowania}

Autorzy składają podziękowanie Instytutowi Meteorologii i Gospodarki Wodnej za udostępnienie danych o opadach z 66 stacji meteorologicznych w Polsce oraz prof. M. Serreze z National Snow and Ice Data Center, University of Colorado Boulder, za możliwość skorzystania z bazy zawierającej informacje o trasach cyklonów na półkuli północnej.

\section{LITERATURA}

Bissolli P., Friedrich K., Rapp J., Ziese M., 2011, Flooding in eastern central Europe in May 2010 - reasons, evolution and climatological assessment, „Weather“, 66(6), s. $147-153$.

Degirmendžić J., Kożuchowski K., Sezonowe wahania liczby niżów śródziemnomorskich w Europie Środkowo-Wschodniej, „Przegląd Geofizyczny” (w druku).

Hann J., 1906, Lehrbuch der Meteorologie, Chr. Herm. Tauchnitz, Leipzig. 642 s.

Kundzewicz Z., Ulbrich U., Brücher T., Graczyk D., Krüger A., Leckebusch G.C., Menzel L., Pińskwar I., Radziejewski M., Szwed M., 2005, Summer Floods in Central Europe - Climate Change Track?, „Natural Hazards”, 36, s. 165-189.

Mudelsee M., Börngen M., Tetzlaff G., Grünewald U., 2004, Extreme floods in central Europe over the past 500 years: Role of cyclone pathway, "Zugstrasse Vb", „Journal of Geophysical Research”, 109, D23101, s. 1-21. DOI:10.1029/2004JD00 5034.

Nissen K.M., Ulbrich U., Leckebusch G.C., Becker N., 2012, Changes in Vb cyclone frequency and rainfall under anthropogenic climate change, „Geophysical Research Abstracts", 14, EGU2012-7040. 
Řezáčová D., Kašpar M., Müller M., Sokol Z., Kakos V., Hanslian D., Pešice P., 2005, A comparison of the flood precipitation episode in August 2002 with historic extreme precipitation events on the Czech territory, „Atmospheric Research”, 77, s. 354-366.

Serreze M.C., 2009, Northern Hemisphere Cyclone Locations and Characteristics from NCEP/NCAR Reanalysis Data, Boulder, Colorado USA: National Snow and Ice Data Center. Digital media, https://nsidc.org/data/docs/daac/nsidc0423_cyclone/.

Sodemann H., Wernli H., Schwierz C., 2009, Sources of water vapour contributing to the Elbe flood in August 2002 - A tagging study in a mesoscale model, „Quarterly Journal of the Royal Meteorological Society", 135, s. 205-223.

Ulbrich U., Brücher T., Fink A.H., Leckebusch G.C., Krüger A., Pinto J.G., 2003, The central European floods of August 2002: Part 2 - Synoptic causes and considerations with respect to climatic change, „Weather”, 58, s. 434-442.

Ustrnul Z., Czekierda D., 2009, Atlas ekstremalnych zjawisk meteorologicznych oraz sytuacji synoptycznych w Polsce, Wydawnictwo IMGW, 182 s.

\section{SUMMARY}

The article presents the course of the average annual trajectory of van Bebber's $\mathrm{Vb}$ cyclones. The most rainfall-efficient section of the trajectory, i.e. the occurrence region of cyclones which produce the highest precipitation in Poland, was delimited. A map of average daily precipitation totals associated with $\mathrm{Vb}$ lows was constructed as well as a map indicating the maximum rainfall i.e. the highest sum of daily precipitation at the weather station in the period 1958-2008 associated with the Vb cyclones situated close to the most rainfall-efficient segment of the trajectory.

$\mathrm{Vb}$ route begins at the Balearic Sea and ends over southern Finland. The highest rainfall in Poland is associated with lows situated in the vicinity of the middle section of the trajectory - over eastern Hungary, western Romania or southern Slovakia. The highest average amount of rainfall can be observed in south-eastern Poland, particularly in the Żywiec dale, in the Tatras, and over the Lublin Upland. Maximum daily rainfall associated with Vb cyclones occurred on Śnieżka peak and reached $129.2 \mathrm{~mm}$.

Keywords: Poland, Mediterranean Vb lows, trajectory, precipitation 